\title{
Phosphorus and Nitrogen in Waters of the Ocoí River Sub-basin, Itaipu Reservoir Tributary
}

\author{
Gilmar S. da Silva, ${ }^{* a}$ Gilberto S. da Silva, ${ }^{b}$ Eliane R. de Sousa, ${ }^{c}$ Cristiane Konrad, ${ }^{c}$ \\ Carla C. Bem, ${ }^{c}$ Janaína Paulic and Adilson Pereira ${ }^{c}$ \\ ${ }^{a}$ Instituto Federal de Educação, Ciência e Tecnologia do Maranhão, Departamento Acadêmico de Química, \\ 65025-000 São Luís-MA, Brazil \\ ${ }^{b}$ Instituto Federal de Educação, Ciência e Tecnologia Goiano, CP. 92, 75650-00 Morrinhos-GO, Brazil \\ 'Universidade Tecnológica Federal do Paraná, 85884-000 Medianeira-PR, Brazil
}

\begin{abstract}
Através da distribuição espacial-temporal das espécies do nitrogênio e do fósforo total na Sub-bacia do Rio Ocoí, tributário do Reservatório de Itaipu, este trabalho avaliou o impacto ambiental nas águas superficiais. Após as chuvas, as fontes difusas predominam, onde o fósforo total e nitrogênio são mais altos. Para o fósforo, os estados tróficos variaram de ultraoligotrófico a mesotrófico. As concentrações atendem à legislação nacional, tanto para águas superficiais quanto potável. Todavia, o nitrogênio total apresenta-se acima dos valores basais, e o nitrito, $0.06 \mathrm{mg} \mathrm{L}^{-1} \mathrm{NO}_{2}^{-} \mathrm{N}$, ficou acima do recomendado para proteção da vida aquática, segundo a Canadian Water Quality Guidelines. O controle das fontes difusas e pontuais é recomendado para minimizar o impacto dos poluentes, ampliando a capacidade de suporte das águas, reduzindo o seu aporte para o Reservatório de Itaipu.
\end{abstract}

Starting from spatial-temporal distribution of nitrogen and phosphorus species in Ocoí river Sub-basin, Itaipu's tributary, this work evaluated the environmental impact in surface waters. After rain, non-point sources are predominant, presenting higher levels of total phosphorus and nitrogen. In the case of phosphorus, trophic states varied from ultraoligotrophic to mesotrophic. Even though Brazilian legislation is obeyed for surface and drinking water, total nitrogen showed values above background levels, and nitrite concentration, $0.06 \mathrm{mg} \mathrm{L}^{-1} \mathrm{NO}_{2}^{-} \mathrm{N}$, lies above the recommended value meant to protect aquatic life, according to the Canadian Water Quality Guidelines. Non-point and point sources control is advisable to minimize environmental phosphorus and nitrogen species impact, increasing the water support capacity and minimizing its discharge into Itaipu Reservoir.

Keyword: Ocoí River, Itaipu Reservoir, phosphorus and nitrogen, principal component analysis, trophic index

\section{Introduction}

Nitrogen and phosphorus species in aquatic systems are known pollutants, ${ }^{1,2}$ but not less important since they are strongly linked with the lifestyle of our society. The European Community, for instance, established a directive that limits phosphorus emission varying from 1 to $2 \mathrm{mg} \mathrm{L}^{-1} \mathrm{P}$ and nitrogen emission from 10 to $15 \mathrm{mg} \mathrm{L}^{-1} \mathrm{~N}$ for wastewater treatment located in risky areas. ${ }^{3}$ Recent studies have discussed the ecotoxicological aspects of $\mathrm{NH}_{3}$ such as water quality index for aquatic life protection, developed by Silva and Jardim. ${ }^{4}$

Nitrogen and phosphorus come from urban-industrial and rural activities such as agriculture and livestock. ${ }^{5,6,7}$ Runoff is the principal transportation means responsible

*e-mail: gilmarsilverio@gmail.com for the discharge into rivers, lakes and reservoirs of great quantities of pollutants. Continuous and reversible reactions along terrestrial and aquatic compartments permit that nitrogen take different toxic forms that affect human and aquatic biota, as nitrite, toxic for aquatic life. ${ }^{1}$ Together with phosphorus, both are responsible for nutrient enrichment of aquatic systems, and its negative consequences like eutrophication. ${ }^{8-11}$ Eutrophication is a process that leads lakes, rivers and reservoirs to impairment, since excessive biomass production can result in alga bloom ${ }^{7}$ and other negative effects, for instance, a cyanobacterium bloom ${ }^{12}$ being responsible for lethal toxins and proliferation of Pfiesteria piscicida, which is a dinoflagellate organism that produces toxins capable of damaging fishes and human beings health. ${ }^{13}$

The Ocoí River's Sub-basin aquatic systems have low flow, inserted in an environment characterized by 
agricultural, pig and poultry farms and urban-industrial activities. The environmental water quality of the Ocoí River has its importance increased by the fact that the Ocoí River is tributary of the Itaipu Reservoir. In order to carry out this work, several field campaigns took place during dry periods and after rainfalls, aiming at assessing nitrogen and phosphorus species and its environmental impact through their spatial-temporal distribution. In this direction, tools as multi variable analysis ${ }^{14,15}$ and the trophic status ${ }^{16-18}$ were used.

\section{Experimental}

Study area

The study area is the Ocoí River Sub-basin (Figure 1), which discharges into the Itaipu Reservoir, and into two of its tributaries, the Alegria River and the Ouro Verde River. These rivers belong to class 2 according to the Conama Directive 357/05 ${ }^{19}$ (Brazilian National Council for the Environment). The Ocoí River Sub-basin is characterized by pig and chicken industrial processes; agriculture, especially soy bean and corn, in which a large quantity of synthetic fertilizer and manure from pig and poultry is applied, following that treated and non-treated municipal wastewater from the cities of Medianeira and Matelândia is discharged into the rivers. Most of the riparian forest area does not obey legal specification, ${ }^{20}$ such as the 30 meters of forest for rivers with less than 10 meters of width, fact that contributes to the pollutants transportation along the drainage area by runoff. The Ocoí River Sub-basin soils are classified as Red Latosol, where degradation of natural vegetation covering takes place, increasing the soil's susceptibility to erosion and creating favorable conditions to carry large loads of sediment. ${ }^{5}$

The study area has subtropical climate with high humidity, hot summers characterized by rainfall accumulation and winter with an average temperature below $18{ }^{\circ} \mathrm{C}$, without a defined dry period. The cities of Medianeira and Matelândia have about 40,000 and 14,000 inhabitants, respectively. In these municipalities, approximately $8 \%$ of the wastewater is treated, while the rest, more than $90 \%$, is discharged into septic or rudimentary tanks ${ }^{21}$ or directly into the rivers.

\section{Collecting samples}

Water samples were collected in six different points, along the three different rivers (Figure 1). The P.1 point is

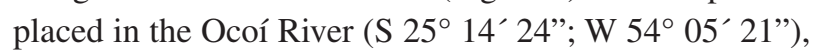
being the one nearest to its headwater. Upstream this point is located one of the Ocoí River's tributaries, the Ocoizinho Stream that receives treated and non-treated wastewater from the city of Matelândia. The P.2 point is located in the Ouro Verde River (S 25 $12^{\prime} 47^{\prime \prime}$; W $54^{\circ} 06^{\prime} 28^{\prime \prime}$ ), another Ocoí River's tributary, which is characterized by typical activities described above, except, recently, for urban-industrial wastewater. The P.3 point is located in the Ocoí River (S $25^{\circ} 13^{\prime} 10^{\prime \prime}$; W $54^{\circ} 06^{\prime} 28^{\prime \prime}$ ), downstream the Ouro Verde River. The P.4 point is located in the Ocoí

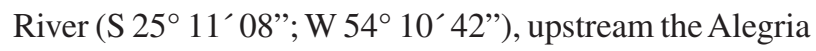
River mouth. The P.5 point is placed in the Alegria River

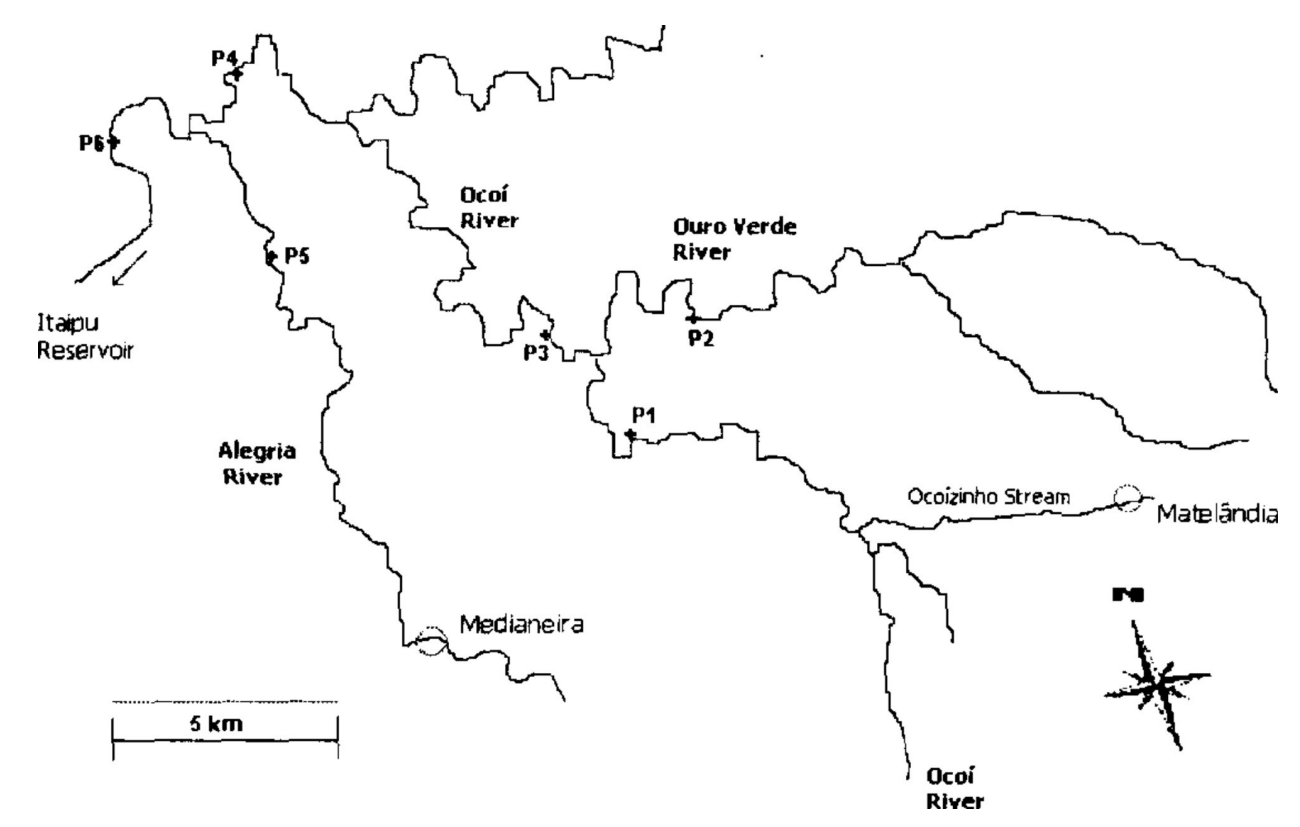

Figure 1. Ocoí River hydrography: the Ocoí, Ouro Verde, Alegria and the Ocoizinho aquatic system. 


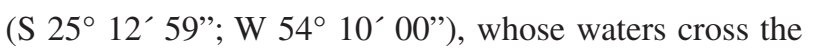
Medianeira city. At this point, industrial and treated and nontreated municipal wastewaters are discharged into the Alegria River. Finally, the P.6 point is the last point in the Ocoí River and is located close to its mouth that flows directly into the Itaipu Reservoir (S 25 $11^{\prime} 40^{\prime \prime}$; W $54^{\circ}$ $\left.12^{\prime} 12^{\prime \prime}\right)$. Samples were collected on the water surface, conserved according to NBR 9898 Protocol $^{22}$ and sent to UTFPR laboratory for following analysis. In total, six field campaigns were carried out between 2005 and 2006.

Table 1 presents dates and runoff conditions during water sampling. Samples with the largest monthly average of rainfall intensity are the 3rd and 4th Campaigns, but only along the 3rd and 6th Campaigns the water samples were collected immediately after the end of the rainfall event, still under influence of surface runoff. Runoff presence is of paramount importance because is responsible for pollutants transportation from the drainage area, and is one kind of non-point source. The 2nd Campaign was carried out after one dry month and possibly was better to represent the Ocoí River Sub-basin behavior without non-point sources in dry period, without runoff.

Table 1. The weather conditions during the water sampling

\begin{tabular}{lccc}
\hline Campaign & Date & $\begin{array}{c}\text { Monthly average of the } \\
\text { rainfall intensity }(\mathrm{mm})\end{array}$ & $\begin{array}{c}\text { Runoff presence/ } \\
\text { absence }\end{array}$ \\
\hline 1st & $07 / 07 / 05$ & 87.7 & absence \\
2nd & $08 / 18 / 05$ & 105.4 & absence \\
3rd & $09 / 01 / 05$ & 261.8 & presence \\
4th & $10 / 20 / 05$ & 413.5 & absence \\
5th & $11 / 24 / 05$ & 81.5 & absence \\
6th & $03 / 23 / 06$ & 137.5 & presence \\
\hline
\end{tabular}

Source: UTFPR-Medianeira weather station

Analysis

Water samples were analyzed according to APHA. ${ }^{23}$ Nitrate $\left(\mathrm{NO}_{3}^{-}\right)$, nitrite $\left(\mathrm{NO}_{2}^{-}\right)$, ammonium $\left(\mathrm{NH}_{3}\right)$ and Total Phosphorus (TP) were measured using UV-Vis spectrophotometer (Fentom, Plus model). The concentrations of $\mathrm{NO}_{3}^{-}$and $\mathrm{NO}_{2}^{-}$were expressed as nitrogen, $\mathrm{mg} \mathrm{L}^{-1} \mathrm{NO}_{3}^{-}-\mathrm{N}$ and $\mathrm{mg} \mathrm{L}^{-1} \mathrm{NO}_{2}^{-}-\mathrm{N}$, respectively. Ammonium $\left(\mathrm{NH}_{3}\right)$ was expressed as nitrogen, $\mathrm{mg} \mathrm{L}^{-1}$ $\mathrm{NH}_{3}-\mathrm{N}$. The total Kjeldahl nitrogen is the combination of organically bound nitrogen and $\mathrm{NH}_{3}$. The combination of the organic nitrogen and the inorganic nitrogen $\left(\mathrm{NH}_{3}, \mathrm{NO}_{3}^{-}\right.$, $\mathrm{NO}_{2}^{-}$) corresponds to the total nitrogen. TP concentration was expressed in $\mathrm{mg} \mathrm{L}^{-1} \mathrm{P}$.

The following parameters were also determined: $\mathrm{pH}$, turbidity, conductivity, ion sodium $\left(\mathrm{Na}^{+}\right)$and ion chloride
$\left(\mathrm{Cl}^{-}\right)$. The sodium $\left(\mathrm{Na}^{+}\right)$concentration was measured by spectrometry of atomic emission using a flame photometer (CELM, model FC-180). The chloride concentration was determined by Mohr method. Each water sample was measured in triplicate and the coefficients of variation are, on average, $8 \%$ for $\mathrm{NO}_{3}^{-}$and $\mathrm{NO}_{2}^{-}, 12 \%$ for $\mathrm{TP}, 5 \%$ for $\mathrm{NH}_{3}$ and $6 \%$ for $\mathrm{Cl}^{-}$.

\section{Statistical analysis}

Principal Component Analysis (PCA) ${ }^{14,24}$ was applied to evaluate the similarity of water samples considering the value of the measured variable. PCA creates a graph of scores that permits to check the relationship using the Euclidean distance, where the new axes, that are orthogonal to each other, correspond to the principal component (PC). Besides a graph of scores, PCA provides a loading graph able to determine the extent of a variable that contributes to each PC axis. PCA was applied to the matrix composed of 6 sampling points (P.1 to P.6) in 5 different campaigns (2nd to 6th), and 6 variables $\left(\mathrm{NH}_{3}, \mathrm{TP}\right.$, conductivity, $\mathrm{Na}^{+}$, $\mathrm{Cl}^{-}$and $\mathrm{pH}$ ), which were previously centered on average due to different orders of magnitude. The matrix submitted to PCA corresponds to 30 water samples (columns) and six variables (lines).

\section{Trophic status index (TSI)}

In order to evaluate the trophic status of the water body, an index created by Carlson, ${ }^{16,17}$ and recently adapted for the rivers of the State of São Paulo by Lamparelli, ${ }^{18}$ was applied. This index can be applied using TP and Chlorophyll a, but this work we used the former parameter, known as the trophic status index based on TP (TSIp), ${ }^{25}$ according to equation 1. TSIp acts as the potential capacity of the aquatic systems to produce biomass in excess, while Chlorophyll $a$ is an effective measure of that biomass. ${ }^{8}$

$T S I p=10(6-(1.77-0.42 \ln \mathrm{TP} / \ln 2))$

where $\mathrm{TP}=$ total phosphorus concentration, in $\mu \mathrm{g} \mathrm{L}^{-1} \mathrm{P}$.

\section{Results and Discussion}

\section{Total phosphorus (TP) behavior}

Table 2 shows $\mathrm{Cl}^{-}$, conductivity, $\mathrm{pH}$, turbidity and $\mathrm{Na}^{+}$ values of water samples from the last 5 campaigns. In the 1st Campaign, only the TP concentration and $\mathrm{NH}_{3}$ were determined. TP and $\mathrm{NH}_{3}$ were shown separately from Table 5 in order to emphasize spatial temporal distribution 
in the Ocoí River waters. In Figure 2 it is possible to observe the temporal-spatial distribution of TP in waters of the Ocoí River.

Table 2. Chemical and physical-chemical parameters measured in the Ocoí River Sub-basin

\begin{tabular}{|c|c|c|c|c|c|}
\hline \multirow[t]{2}{*}{ Parameters $^{1}$} & \multicolumn{5}{|c|}{ Campaigns } \\
\hline & 2nd & $3 \mathrm{rd}$ & 4th & 5 th & 6th \\
\hline \multicolumn{6}{|l|}{ P.1 Point } \\
\hline $\mathrm{Cl}$ & 71.6 & 14.9 & 27.8 & 9.2 & 9.9 \\
\hline Conductivity & 84 & 94 & 91 & 124 & 386 \\
\hline $\mathrm{pH}$ & 7.19 & 7.17 & 7.58 & 7.38 & 7.2 \\
\hline Turbidity & - & - & 11 & 7 & 766 \\
\hline $\mathrm{Na}$ & 12.2 & 10.3 & 8.4 & 8.8 & 11.3 \\
\hline \multicolumn{6}{|l|}{ P. 2 Point } \\
\hline $\mathrm{Cl}$ & 64.6 & 12.9 & 25.8 & 8.5 & 10.7 \\
\hline Conductivity & 102 & 91 & 95 & 237 & 168 \\
\hline $\mathrm{pH}$ & 6.9 & 7.3 & 7.4 & 7.3 & 7.3 \\
\hline Turbidity & - & - & 8 & 3 & 351 \\
\hline $\mathrm{Na}$ & 15 & 10.3 & 9.3 & 9.6 & 10.8 \\
\hline \multicolumn{6}{|l|}{ P.3 Point } \\
\hline $\mathrm{Cl}$ & 81.5 & 18.9 & 27.8 & 6.4 & 9.2 \\
\hline Conductivity & 94 & 86 & 89 & 141 & 195 \\
\hline $\mathrm{pH}$ & 7.4 & 7.31 & 7.47 & 7.65 & 7.3 \\
\hline Turbidity & - & - & 8 & 7 & 701 \\
\hline $\mathrm{Na}$ & 14.1 & 10.3 & 9.3 & 10.1 & 10.3 \\
\hline \multicolumn{6}{|l|}{ P.4 Point } \\
\hline $\mathrm{Cl}^{-}$ & 70.6 & 18.9 & 24.9 & 7.8 & 9.9 \\
\hline Conductivity & 94 & 89 & 93 & 79 & 137 \\
\hline $\mathrm{pH}$ & 7.3 & 7.4 & 7.7 & 7.7 & 7.4 \\
\hline Turbidity & - & - & 10 & 5 & 512 \\
\hline $\mathrm{Na}$ & 13.2 & 11.3 & 10.3 & 10.5 & 11 \\
\hline \multicolumn{6}{|l|}{ P.5 Point } \\
\hline $\mathrm{Cl}^{-}$ & 118.3 & 52.7 & 34.8 & 9.2 & 16.3 \\
\hline Conductivity & 237 & 143 & 104 & 70 & 137 \\
\hline $\mathrm{pH}$ & 7.09 & 7.16 & 7.62 & 7.53 & 7.2 \\
\hline Turbidity & - & - & 21 & 16 & 497 \\
\hline $\mathrm{Na}$ & 37.6 & 25.4 & 15.9 & 18.3 & 23.4 \\
\hline \multicolumn{6}{|l|}{ P.6 Point } \\
\hline $\mathrm{Cl}^{-}$ & 73.6 & 23.9 & 29.8 & 7.8 & 9.9 \\
\hline Conductivity & 87 & 93 & 105 & 75 & 117 \\
\hline $\mathrm{pH}$ & 7.28 & 7.33 & 6.62 & 7.57 & 7.4 \\
\hline Turbidity & - & - & 10 & 7 & 633 \\
\hline $\mathrm{Na}$ & 16 & 13.2 & 10.3 & 11 & 12.2 \\
\hline
\end{tabular}

In Figure 2 results of the TP concentration for the P.1, P.3, P.4 and P.6 points, that belong to Ocoí River, show values below the limit-values established by the Conama Directive $357 / 05,{ }^{19} 0.05 \mathrm{mg} \mathrm{L}^{-1} \mathrm{P}$, except for the 3rd Campaign, when all points had its TP concentrations exceeding the limit-value. In addition, during the 3rd campaign, P.5 point, located in the Alegria River, showed the TP concentration of $0.11 \mathrm{mg} \mathrm{L}^{-1} \mathrm{P}$, close to the limitvalue required by legislation, $0.10 \mathrm{mg} \mathrm{L}^{-1} \mathrm{P}$. The reason for the high TP values observed in the 3rd campaign can be attributed to rainfall few hours before water sampling, when runoff still was present, suggesting a significant presence of phosphorus input from non-point sources. One kind of non-point source is surface waters that drain the Ocoí River Sub-basin. They can load different phosphorus species, especially phosphorus adsorbed on mineral particles. The soil of the area is rich in clay minerals and oxides like gibbsite and goethite, known for their capacity of adsorbing phosphate. ${ }^{26,27}$

The P.5 point shows high TP concentration compared with the other sampling points during rain or dry periods. During the dry period, urban-industrial wastewater from the Medianeira city predominates and, during the rainfall, there is likely the contribution of unidentified non-point sources too. It is important to emphasize that all points in the Ocoí River, P.1, P.3, P.4 and P.6, independently of the season, show a relatively similar TP value. In addition, if the only source of phosphorus was runoff, in the dry period and under absence of point source, the TP concentration values should be very small compared with dry period with point source, for instance, Alegria River (P.5 point) in the 2nd campaign. This behavior did not occur. As it can be seen, the P.3 point during 2nd campaign shows $0.038 \mathrm{mg} \mathrm{L}^{-1} \mathrm{P}$, higher than P.5 point, which was $0.031 \mathrm{mg} \mathrm{L}^{-1} \mathrm{P}$. The same occurs between the points P.1 and P.5 in the 4th campaign. The results suggest that there should be a non-point source acting independently of runoff. In this direction, it is important to mention that the Ocoízinho Stream is a nonpoint source that provides TP during the entire year. Finally, in order to understand why the P.3 point, in the Ocoí River, showed TP concentration higher than the P.5 point, although it did not rain during the 2nd Campaign, it is necessary to consider non-point sources that act independently of rainfall and, therefore, runoff. Those non-point sources may be an animal waste discharge from farms, which exist in a large number along the banks. ${ }^{10}$

\section{Trophic status index}

In order to evaluate the trophic status of the Ocoí River and its tributaries, Alegria and Ouro Verde rivers, 


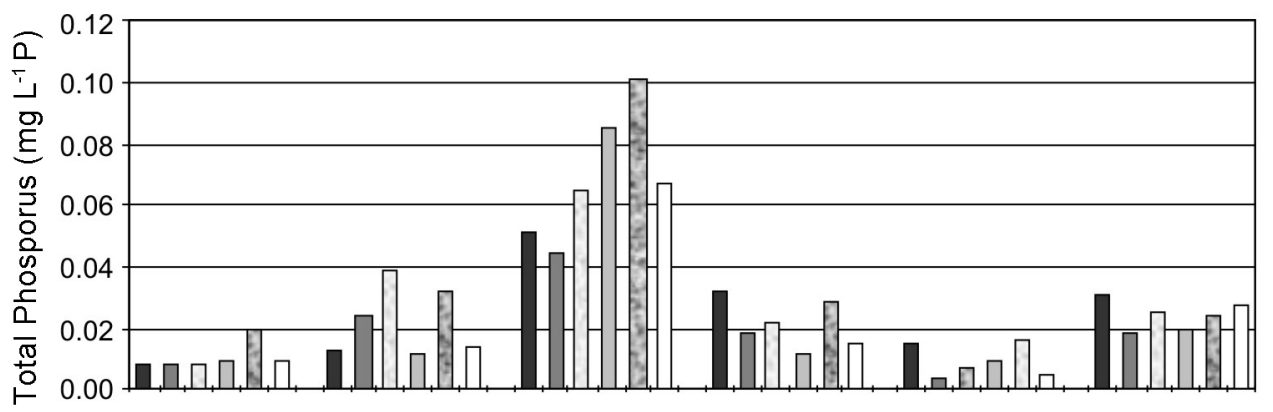

(a)

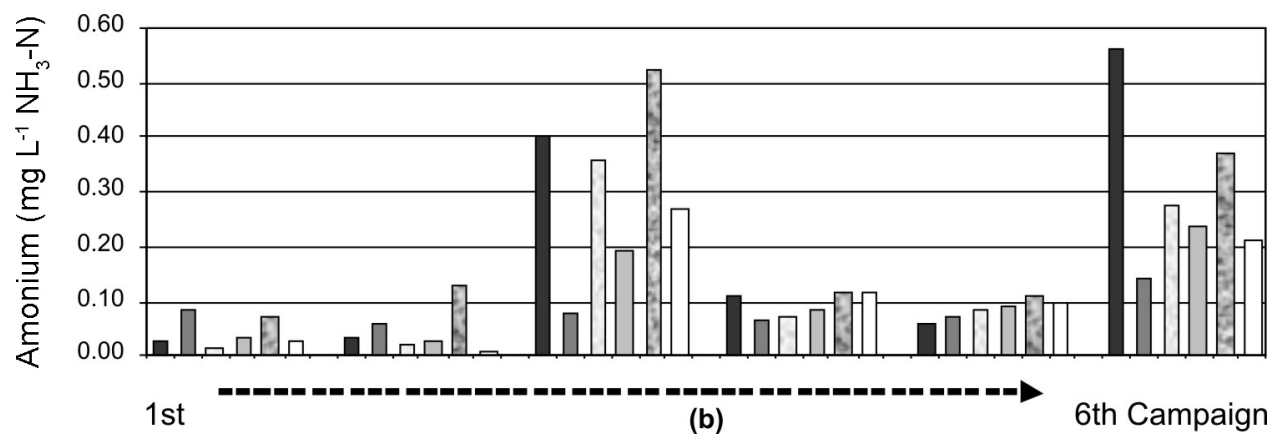

Figure 2. The spatial-temporal distribution of the $\mathrm{TP}$ and $\mathrm{NH}_{3}$ from $\mathrm{P} 1$ to $\mathrm{P} 6$ point at Ocoí River Sub-basin. Water samples have influence of runoff during the 3rd and 6th Campaigns. Legend: P1 (dark column) until P6 (white column).

the trophic status index (TSIp) was applied based on the TP concentration. ${ }^{25}$ In Table 3, the TSIp results from six sampling points during all campaigns are presented, which categories varied from ultraligotrophic (TSIp $\leq 47$; $\left.\mathrm{P} \leq 13 \mu \mathrm{g} \mathrm{L}^{-1} \mathrm{P}\right)$ to mesotrophic $(52<\mathrm{TSIp} \leq 59$; $35<\mathrm{P} \leq 137 \mu \mathrm{g} \mathrm{L}{ }^{-1} \mathrm{P}$ ) classes. In the 3rd Campaign the TSIp was the most critical, presenting mesotrophic waters, being the P.5 point, the Alegria River, responsible for the highest TSIp, 57.9. The mesotrophic status indicates a water body with intermediate biomass productivity, and still does not represent water impairment in most of situations. In the other campaigns, the trophic status remained between ultraoligotrophic and oligotrophic
(47 < TSIp $\left.\leq 52 ; 13<\mathrm{P} \leq 35 \mu \mathrm{g} \mathrm{L}{ }^{-1} \mathrm{P}\right)$, demonstrating satisfactory water conditions. It is necessary to emphasize that, in general, the P.5 point in the Alegria River, shows the worst TSIp, and probably because is doubly affected by both non-point and point sources, being the latter from urban-industrial wastewater. Another important point is the P.3, in the 2nd Campaign, whose water was classified as mesotrophic. The reason for this high TSIp was mentioned above. In general, it is worth to mention that point and non-point polluting sources, independent of the rainfall, which discharge into water bodies when flow and water velocity are low, are more favorable for biomass production. ${ }^{9,28,29}$

Table 3. The Trophic Status Index (TSIp) values of the Ocoí River and its tributaries

\begin{tabular}{lcccccccccccc}
\hline Point & \multicolumn{2}{c}{ 1st Campaign } & \multicolumn{2}{c}{ 2nd Campaign } & \multicolumn{2}{c}{ 3rd Campaign } & \multicolumn{2}{c}{ 4th Campaign } & \multicolumn{2}{c}{ 5th Campaign } & 6th Campaign \\
\cline { 2 - 13 } & TSIp & Class & TSIp & Class & TSIp & Class & TSIp & Class & TSIp & Class & TSIp & Class \\
\hline P1 & 45.0 & Ultra* & 47.0 & Ultra & 54.4 & Meso $^{\text {b }}$ & 52.1 & meso & 47.7 & Oligo & 51.7 & Oligo \\
P2 & 44.7 & Ultra & 50.5 & Oligo & 53.8 & meso & 49.2 & Oligo & 40.7 & Ultra & 49.0 & Ultra \\
P3 & 44.9 & Ultra & 52.9 & meso & 55.6 & meso & 50.0 & Oligo & 44.6 & Oligo & 50.7 & Ultra \\
P4 & 45.4 & Ultra & 46.3 & Oligo & 57.0 & meso & 46.7 & Ultra & 45.4 & Oligo & 49.5 & Ultra \\
P5 & 49.5 & Oligo $^{\mathrm{a}}$ & 51.9 & Oligo & 57.9 & meso & 51.4 & Oligo & 48.5 & Oligo & 50.5 & Oligo \\
P6 & 45.5 & Ultra & 47.6 & Oligo & 55.8 & meso & 48.1 & Oligo & 41.7 & Ultra & 51.1 & Ultra \\
\hline
\end{tabular}

* ultraoligotrophic, ${ }^{\mathrm{a}}$ oligotrophic, ${ }^{\mathrm{b}}$ mesotrophic 
$\mathrm{NH}_{3}, \mathrm{NO}_{3}^{-}$and $\mathrm{NO}_{2}^{-}$behavior

Due to $\mathrm{NH}_{3}$ ecotoxicity, this substance plays an important role for the aquatic life protection. ${ }^{5}$ According to the Conama Directive $375 / 05,{ }^{19}$ the limited values of $\mathrm{NH}_{3}$ in water bodies class 2 are $3.7 \mathrm{mg} \mathrm{L}^{-1} \mathrm{NH}_{3}-\mathrm{N}$ to $\mathrm{pH}<7.5$ and $2 \mathrm{mg} \mathrm{L}^{-1} \mathrm{NH}_{3}-\mathrm{N}$ to $\mathrm{pH}>7.5$. Figure 2 presents the $\mathrm{NH}_{3}$ concentration in the river water. The maximum values did not exceed $0.7 \mathrm{mg} \mathrm{L}^{-1} \mathrm{NH}_{3}-\mathrm{N}$, below the limit-value. On the other hand, the lowest $\mathrm{NH}_{3}$ concentration was observed in the water samples collected without rainfall, during the 1st, 2 nd, 4 th and 5th Campaigns, where runoff was no longer present in the Ocoí River Sub-basin. Among the high value observed in the presence of runoff, $3 \mathrm{rd}$ and 6 th campaigns, the value of P.1 point, the nearest to the Ocoí River's headwaters, was higher than the ones of other points, except the P.5 point. This result suggests significant non-point sources activated by runoff. The transport of $\mathrm{NH}_{3}$ in the soil where pig and poultry manure has been spread out depends on the interval between the application and the first rains. In general, on the first days $\mathrm{NH} 3$ prevailed. With time, a decrease in the initial $\mathrm{NH}_{3}$ concentration takes place, firstly because of the nitrification process ${ }^{30}$ increasing the $\mathrm{NO}_{3}^{-}$production, and secondly because volatilization of ammonia to atmosphere. The transport of the nitrogen species has different characteristics. $\mathrm{As}^{\mathrm{NO}_{3}}$ is very soluble in the water and due to its negative charge it is not adsorbed by the mineral particles, ${ }^{31}$ on the other hand, $\mathrm{NH}_{3}$ can be converted into $\mathrm{NH}_{4}^{+}$in the soil, where positive charge contribute to its adsorption by the particles.

The P.5 point stands out, presenting higher $\mathrm{NH}_{3}$ concentration than the other points practically in all campaigns, with observed for TP. This behavior agrees with the fact that Alegria River receives both non-point and point sources, what explains not only high $\mathrm{NH}_{3}$ concentration, but the high level of TP as well.

To give initial information about distribution of nitrogen species in these water bodies, in Table 4 are presented different concentrations of them for only the 6th Campaign: $\mathrm{NH}_{3}, \mathrm{NO}_{3}^{-}, \mathrm{NO}_{2}^{-}$and $\mathrm{TN} .^{32}$ The $\mathrm{NO}_{2}^{-}$concentration values varied from 0.024 to $0.240 \mathrm{mg} \mathrm{L}^{-1} \mathrm{NO}_{2}^{-}-\mathrm{N}$, and $\mathrm{NO}_{3}^{-}$varied from 0.099 to $0.167 \mathrm{mg} \mathrm{L}^{-1} \mathrm{NO}_{3}^{-}-\mathrm{N}$. At the P.5 point, the $\mathrm{NO}_{2}^{-}$concentration was $0.240 \mathrm{mg} \mathrm{L}^{-1} \mathrm{NO}_{2}^{-}-\mathrm{N}$, higher than $\mathrm{NO}_{3}^{-}, 0.133 \mathrm{mg} \mathrm{L}^{-1} \mathrm{NO}_{3}^{-}-\mathrm{N}$, corroborating the influence of urban-industrial wastewater. Urban-industrial wastewater can discharge a large quantity of $\mathrm{NH}_{3}$ into the rivers, which can be rapidly converted into $\mathrm{NO}_{2}^{-}$and, later, $\mathrm{NO}_{3}^{-}$. In a broad aspect, the $\mathrm{NH}_{3}$ concentration was higher than nitrogen oxidized forms for all points, suggesting recent pollutant discharge.

In order to evaluate nitrogen species impact in aquatic life, it is necessary to regard, besides $\mathrm{NH}_{3}$, the
Table 4. The Ocoí River's nitrogen species. The 6th Campaign was carried out after runoff

\begin{tabular}{lcccc}
\hline Point & $\mathrm{NH}_{3}-\mathrm{N}$ & $\mathrm{NO}_{2}-\mathrm{N}$ & $\mathrm{NO}_{3}-\mathrm{N}$ & $\mathrm{TN}$ \\
\hline P1 & $0.569 \pm 0.028$ & $0.107 \pm 0.013$ & $0.210 \pm 0.025$ & 2.625 \\
P2 & $0.140 \pm 0.011$ & $0.043 \pm 0.004$ & $0.099 \pm 0.012$ & 7.452 \\
P3 & $0.272 \pm 0.024$ & $0.067 \pm 0.008$ & $0.131 \pm 0.011$ & 0.470 \\
P4 & $0.239 \pm 0.014$ & $0.049 \pm 0.003$ & $0.167 \pm 0.011$ & 3.705 \\
P5 & $0.371 \pm 0.029$ & $0.240 \pm 0.028$ & $0.133 \pm 0.016$ & 2.145 \\
P6 & $0.206 \pm 0.016$ & $0.024 \pm 0.002$ & $0.122 \pm 0.013$ & 0.632 \\
\hline
\end{tabular}

Source: $* \mathrm{TN}$ corresponds to all nitrogen species: organic and inorganic.

oxidized nitrogen form, $\mathrm{NO}_{2}^{-}$. High $\mathrm{NO}_{2}^{-}$concentration can cause harmful effects on aquatic life. The Canadian Water Quality Guidelines (CCME, 2001) ${ }^{33}$ establishes $0.06 \mathrm{mg} \mathrm{L}^{-1} \mathrm{NO}_{2}^{-}-\mathrm{N}$ for protection of sensitive living organism in the water bodies. According to Table 7, the points P.1, P.3 and P.5 showed $\mathrm{NO}_{2}^{-}$concentration above of the $0.06 \mathrm{mg} \mathrm{L}^{-1} \mathrm{NO}_{2}^{-}-\mathrm{N}$. Since $\mathrm{NO}_{3}^{-}$can be reduced to $\mathrm{NO}_{2}^{-}$, the same guideline recommends maximum interim value of $13 \mathrm{mg} \mathrm{L}^{-1} \mathrm{NO}_{3}^{-}-\mathrm{N}$.

In addition, the oxidized nitrogen, $\mathrm{NO}_{2}^{-}$and $\mathrm{NO}_{3}^{-}$, are species that deserve rigorous control when the subject is human health. With this direction, $\mathrm{NO}_{2}^{-}$and $\mathrm{NO}_{3}^{-}$are limited by the Conama Directive $357 / 05^{19}$ in $1 \mathrm{mg} \mathrm{L}^{-1} \mathrm{NO}_{2}^{-}-\mathrm{N}$ and $10 \mathrm{mg} \mathrm{L}^{-1} \mathrm{NO}_{3}^{-}-\mathrm{N}$, respectively. Those values are the same required for drink waters according to the Federal Law $n^{\circ} .518 / 2004$ of the Brazilian Health Ministry. ${ }^{34}$ Therefore, all water samples obeyed the legislation for drinkable water.

The nitrogen species described above, $\mathrm{NH}_{3}, \mathrm{NO}_{2}^{-}$and $\mathrm{NO}_{3}^{-}$, not only are toxic for living beings, but they contribute to total nitrogen (TN) bulk in the body of water. TN can enrich aquatic ecosystem leading to excessive biomass production. In this case, the bulk of TN in the water body may function as trophic status index in aquatic systems, similar to TP, since both are essential macronutrients. Table 4 shows the TN concentration values, which varied from $2.63 \mathrm{mg} \mathrm{L}^{-1} \mathrm{~N}$ at the P.1 point (the nearest to Ocoí River's headwaters) to $7.5 \mathrm{mg} \mathrm{L}^{-1} \mathrm{~N}$ at the P.2 point, the Ouro Verde River. Those values are considered high compared with other aquatic systems, where it is considered a basal level ${ }^{35}$ of $1 \mathrm{mg} \mathrm{L}^{-1} \mathrm{~N}$. If the limited value of TN proposed by Dodds et al., ${ }^{36}$ are adopted for streams in temperate environment, i.e. $0.7 \mathrm{mg} \mathrm{L}^{-1} \mathrm{~N}$ for oligotrophic water bodies, and $1.5 \mathrm{mg} \mathrm{L}^{-1} \mathrm{~N}$ for eutrophic/mesotrophic limit, the results showed in Table 4 indicate that the water can be classified as eutrophic for P.1, P.2, P.4 and P.5 points.

\section{Principal Component Analyses}

According to the eiginvalues showed in Table 5, PC1 and $\mathrm{PC} 2$ account for the total variance, $83.72 \%$ and $15.44 \%$, 
respectively, being $99.16 \%$ the cumulative eigenvalues for both components. The PC1 has great influence on group 1 separation, while $\mathrm{PC} 2$ on group 2. In this latter group, the water samples correspond to the 2nd Campaign, which better represents sources independent of rainfall (Figure 3) ${ }^{32}$ In this group 2, only the P.5 point remained separated, suggesting a different chemical behavior from the other points, probably because the Alegria River is a receiving water body of the urban-industrial wastewater from Medianeira city. In contrast, the P.5 point in the other campaigns is more similar to other points because urban-industrial wastewaters are no longer so predominant compared to non-point source activated by rainfall event.

Table 5. \% Eigenvalue and Cumulative \% eigenvalues to PCA analyses of water sample form Ocoí River Sub-basin

\begin{tabular}{lcc}
\hline Principal Component & \% Eigenvalue & $\begin{array}{c}\text { Cumulative \% } \\
\text { eigenvalues }\end{array}$ \\
\hline PC1 & 83.721 & 83.721 \\
PC2 & 15.443 & 99.164 \\
PC3 & 0.835 & 99.999 \\
PC4 & 0.001 & 100 \\
PC5 & 0 & 100 \\
PC6 & 0 & 100 \\
\hline
\end{tabular}

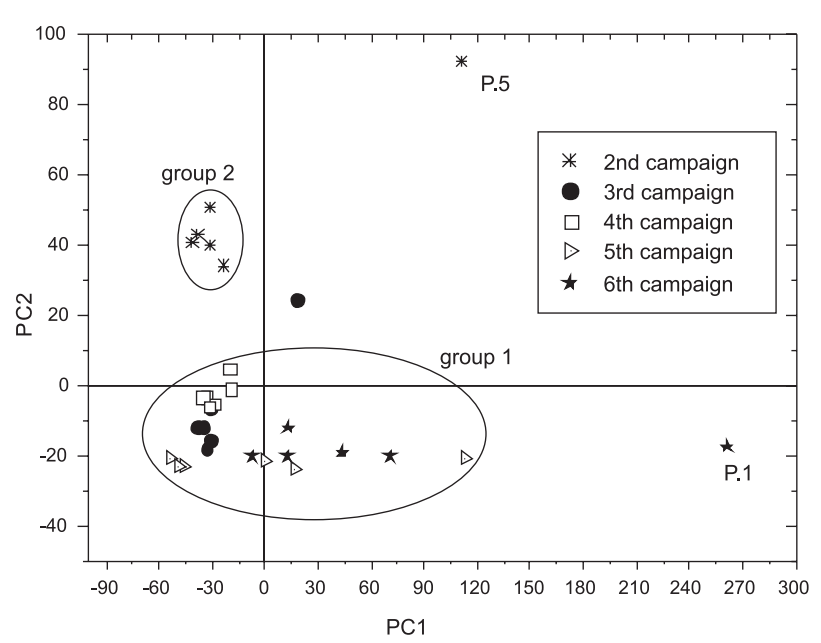

Figure 3. The Score graph for the first two principal components, $\mathrm{PC} 1 \times \mathrm{PC} 2$.

As to identify which variable had the highest influence on PC1 and PC2, loading values were used (Figure 4). According to loadings values, cond. is the almost exclusively variable that contributes to $\mathrm{PC} 1$, loading 1 , as other parameters were much smaller: $\mathrm{Cl}^{-}\left(-1.45 \times 10^{-2}\right)$, $\mathrm{pH}\left(-7.73 \times 10^{-4}\right), \mathrm{Na}^{+}\left(1.99 \times 10^{-2}\right)$, PT $\left(-6.68 \times 10^{-5}\right)$ and $\mathrm{NH}_{3}\left(1.32 \times 10^{-3}\right)$. These results can suggest that dissolved electrolytes from runoff increase conductivity in water bodies. Rainfall and specific features of each drain area vary along the river (surface vegetation coverage, soil topography, riparian forest, etc.); therefore, it is expected that different electrolyte loads be discharged into the water bodies, which helps to explain dispersion of group 1. In this scenery, the P.1 point of the 2nd Campaign remained isolated (Figure 4), showing great susceptibility to nonpoint sources, what may help to explain $\mathrm{TP}$ and $\mathrm{NH}_{3}$ high concentrations in the same point.

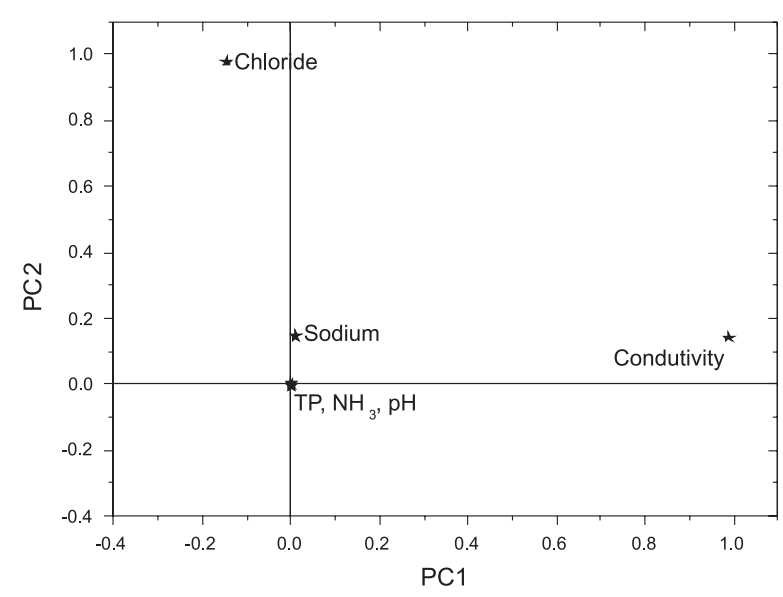

Figure 4. Loading graph for the two principal components, $\mathrm{PC} 1$ and $\mathrm{PC} 2$.

To PC2, $\mathrm{Cl}^{-}$has a loading of 0.99 and it is almost responsible by group 2 separation. Other parameters were: Cond. $\left(1.16 \times 10^{-2}\right), \mathrm{pH}\left(-2.83 \times 10^{-3}\right), \mathrm{Na}^{+}\left(1.38 \times 10^{-1}\right), \mathrm{PT}\left(1.39 \times 10^{-4}\right)$ and $\mathrm{NH}_{3}\left(-1.54 \times 10^{-3}\right)$. $\mathrm{Cl}^{-}$from non-point source was not correlated with conductivity, as it can be seen in the loading graph, because they are orthogonal. The highest concentrations of this ion occur during low flow, without water contribution from runoff, especially in the 2nd Campaign, where the P.5 point in the Alegria River reached $118.29 \mathrm{mg} \mathrm{L}^{-1} \mathrm{Cl}^{-}$; probably due to the presence of urbanindustrial wastewater. It should be emphasized that all water samples from the 2nd Campaign presented the highest $\mathrm{Cl}^{-}$ concentration, suggesting that non-point and point sources independent of rainfall may act during the dry period, once the $\mathrm{Cl}^{-}$is typically a species from the animal and urbanindustrial wastewater. ${ }^{24}$ Loadings to $\mathrm{Na}^{+}, \mathrm{pH}, \mathrm{PT}$ and $\mathrm{NH}_{3}$ are so low, much close to the axis origin, and contribute little to components. However, the absence of significant loading implies that there are no predominant $\mathrm{PT}$ or $\mathrm{NH}_{3}$ sources in watershed, corroborating the idea that different pollutants' transportation mechanisms are acting along the ecosystem.

\section{Conclusions}

The results point out the presence of phosphorus and nitrogen from non-point and point sources acting in the Ocoí River Sub-basin. Non-point sources are more 
predominant and identifiable after rainfall, due to runoff, and sometimes only the TP exceeds the Conama Directive 357/05 requirements, contrasting with $\mathrm{NH}_{3}$, which remained below the limit-value. In general, phosphorus and ammonium showed the highest concentration under runoff influence. Phosphorus impact in the water quality, according to modified Carlson Trophic Index, indicates trophic class varying from oligotrophic to mesotrophic. The latter class occurred in the presence of runoff. Nitrogen species are below the Brazilian law requirements for surface and drinkable water, as well as for aquatic protection life, although the bulk of total nitrogen can be considered high compared to basal level. However, nitrite concentration showed high values regarding the Canadian Water Quality Guidelines, above $0.06 \mathrm{mg} \mathrm{L}^{-1} \mathrm{NO}_{2}^{-}-\mathrm{N}$.

The Analysis of the Principal Component indicates two principal components, $\mathrm{PC} 1$ and $\mathrm{PC} 2$, which are able to separate two groups of water samples. Chloride $\left(\mathrm{Cl}^{-}\right)$ was mainly responsible for separating the water samples that corresponded to the dry period. High Chloride $\left(\mathrm{Cl}^{-}\right)$ concentration suggests also the presence of the non-point and point sources independent of runoff. Probably, nonpoint source independently of runoff can be the reason why during the dry period mesotrophic class was also observed in the Ouro Verde and the Ocoí rivers. The Alegria River is influenced by both non-point and point sources, being more susceptible in the future due to load increase from growing industrial and domestic activities.

\section{Acknowledgements}

The authors thank Fundação Araucária, Fundação Parque Tecnológico de Itaipu (FPTI) and UTFPR/Campus Medianeira for financial support.

\section{References}

1. Koo, B. K.; 0'Connell, P. E.; Sci. Total Environ. 2006, 359, 1.

2. Lewis JR, W. M.; Donald, P. M.; Transactions of the American Fisheries Society 1986, 115, 183.

3. E.E.C. (European Economic Community); Directive 91/271/ EEC, on Urban waste water treatment, 1991. http://eur-lex. europa.eu/pt/index.htm, accessed in July 2008.

4. Silva, G. S. ; Jardim, W. F.; Quim. Nova 2006, 29, 689.

5. Hooda, P. S.; Moynagh, M.; Svoboda, L. F.; Thurlow, M.; Stewart, M.; Thomson, M.; Anderson, H.A.; Sci. Total Environ. 1997, 201, 63.

6. Chapman, A S.; Foster, 1. D.; Lees, J. A; Hodgkinson, R. A; Jackson, R. H.; Sci. Total Environ. 2001, 66, 95.

7. Kyllmar, K.; Carisson, C.; Gustafson, A; Ulén, B.; Johnsson, H. Agr Ecosyst Environ. 2006, 115, 15.
8. Spivakov, B. YA.; Maryutina T. A.; Muntau, H.; Pure Appl. Chem. 1999, 71, 2161.

9. United States Environmental Protection Agency, USEPA; Nutrient Criteria-Technical Guidance Manual-Rivers and Streams -EPA 822-BOO-002, Washington, DC, 2000, http:// www.epa.gov/waterscience/criteria/nutrient/guidance/rivers/ index.html, accessed in July 2008.

10. United States Environmental Protection Agency (USEPA); Protocol for Developing Nutrient TMDLs - EPA 841-B-99007, Washington D.C., 1999, http://www.epa.gov/owow/tmdl/ nutrient/pdf/nutrient.pdf, accessed in July 2008.

11. Bowes, M.J; House, W. A; Hodgkinson, R. A.; Sci. Total Environ. 2003, 313, 199.

12. Falconeri, I. R.; Humpage, A . R.; Int. J. Environ. Res. Public Health 2005, 2, 43

13. Burkholder, J. M.; GlasgowJr, H. B.; Limnol. Oceanogr. 1997, 42, 1052.

14. Beebe, K. R.; Pell, R. J.; Seasholtz, M. B.; Chemometrics: A Practical Guide, $1^{\text {st }}$ Ed. Wiley-Interscience:NewYork, 1998.

15. Sousa, E. R.; PhD Thesis, Instituto de Química da Universidade Estadual de Campinas, Brasil, 2005.

16. Carlson, R. E.; Limnol. Oceanogr. 1997, 22, 361.

17. Toledo Jr., A. P.; Agudo, E. G.; Talarico, M.; Chinez, S. J.; XIX Congresso Interamericano de Engenharia Sanitária AmbientalAIDIS, Santiago do Chile, Chile, 1984.

18. Lamparelli, M. C.; PhD Thesis, Instituto de Biociências da Universidade de São Paulo, Brasil, 2004.

19. Portaria 365/05, http://www.mma.gov.br/port/conama, accessed in February de 2009.

20. Lei $\mathrm{N}^{\circ} 7.803$ de 18 de Julho de 1989. Diário Oficial da União. 20/07/1989. http://www.planalto.gov.br/ccivil_03/Leis/L7803. htm, acessed in July 2008

21. http://www.cnm.org.br/infra/, accessed in February 2009.

22. Associação Brasileira de Normas Técnicas, ABNT; NBR 9898: Preservação e técnicas de amostragem de efluentes líquidos e corpos receptores, Rio de Janeiro, Brasil, 1987.

23. American Public Health Association, APHA; Standard Methods for the Examination of Water and Wastewater. 16. ed., American Water Works Association and Water Pollution Control Federation: Washington, DC, 1985.

24. Sodré, F. F.; Anjos, V. E.; Prestes, E. C.; Grassi, M. T.; J. Environ. Monit. 2005, 7, 581.

25. Companhia de Tecnologia de Saneamento Ambiental, CETESB; Relatório de Qualidade das Águas Interiores do Estado de São Paulo, São Paulo, Brasil, 2004.

26. Bowes M. J.; House W. A.; Hodgkinson R. A.; Sci. Total Environ. 2003, 313, 199.

27. House, W. A.; Leach, D.; Warwick, M.S.; Whitton, B. A.; Pattison, S. N.; Ryland, G.; Pinder, A; Ingram, J.; Lishman, J. P.; Smith, J. M.; Rig, E.; Denison, F. H; Sci. Total Environ., 1995, 194, 303. 
28. Mainstone, C. P.; Parr, W.; Sci. Total Environ. 2002, 25, 282.

29. Jarvie, H. P.; Neal, C.; Withers, P. J.; Sc. Total Environ. 2006, $360,246$.

30. Ceretta, C. A. ; Basso, C. J.; Vieira, F. C. B.; Herbes, M. G.; Moreira, 1. C. L; Berwanger, A L.; Cienc. Rural 2005, 35, 1296.

31. Jarvie, H. P.; Whitton, B. A; Neal. C.; Sci. Total Environ. 1998, 210/211, 79.

32. Silva, G. S.; Konrad, C.; Pauli, J. ; Silva, G. S.; Sousa, E. R. Abstract of the do XI Seminário de Iniciação Científica e Tecnológica, Curitiba, Brasil, 2006.

33. http://www.ccme.ca/ accessed in February 2009.
34. Ministério da Saúde; Portaria n ${ }^{\circ} .518$ de 25 de março de 2004, Brasília DF, 2004. http://portal.saude.gov.br/portal/arquivos/ pdf/portaria_518_2004.pdf, acessed in July 2008

35. United States Geological Survey, USGS; The Quality of Our Nation's Waters - Nutrients and Pesticides: U.S Geological survey Circular 1999, 1225, 82.

36. Dodds, W. K.; Jones, J. R.; Weich, E. B.; Water Res. 1998, 32 , 1455 .

Received: October 15, 2008

Web Release Date: August 31, 2008 